SHS Web of Conferences 2, 00005 (2012)

DOI: $10.1051 /$ shsconf $/ 20120200005$

(C) Owned by the authors, published by EDP Sciences, 2012

\title{
The role of responsive regulation in taxation
}

\author{
M. Belevich \\ Rīga Stradiņš University, Latvia
}

\begin{abstract}
This paper is aimed to show the role of responsive regulation in taxation on the example of such a legal remedy as the settlement agreement between taxpayer and tax administration in the jurisdiction of Latvia. The legal framework and resent case law of is analyzed on the basis of comparison with the latest research in the sphere of responsive regulation and the practical implementation of responsive regulation instruments in the other jurisdictions. The author of the paper comes to the conclusion that the existing legal model of settlement agreement is not efficient and it should be changed to the model that ensures the interests of taxpayers and tax administration in the optimal way.
\end{abstract}

Key words: responsive regulation, taxpayer, settlement agreement

No one can deny that the issues of taxation are directly connected to the issues of society's welfare; the state's tax incomes are the only guarantee of the effective realization of any kind of social programs. The aim of any state is the high levels of voluntary tax compliance. So the key issue of almost any scientific research in taxation is the remedies: economic, social, political, legal or even psychological of making the tax compliance really voluntary.

In this paper the innovative approach in tax compliance which is called "responsive regulation" is shown. This method can ensure such important factors of compliance as efficiency and vulnerability. The use of such an instrument of responsive regulation as the settlement agreement is the key issue of this paper.

\section{Discussion}

According to the definition of the pioneer of the responsive regulation institute - Valerie Braithwaite, the professor of the Australian National University "The implementation of responsive regulation in taxation means influencing the community's commitment to pay tax trough respectful treatment, trough attending to resistance and reforming faulty process, trough fairly directed and fully explained disapproval of non-compliant behavior, trough preparedness to administer sanctions, and capacity to follow through to escalate regulatory intervention in the face of continuing non-compliance" (Braithwaite, 2007).

In the author's eyes the institute of the settlement agreement in tax sphere fully corresponds to the aims of responsive regulation. The Latvian legal regulation of the settlement agreement doesn't state the aim of the settlement agreement; it is stated in the case law - the aim of the settlement agreement is to ensure the effective proceeding of the tax administration functions. The settlement agreement between taxpayer and tax administration is the remedy, which is used by the tax authority in order to get back the unpaid taxes promptly, not spending state recourses on long lasting debates proving the assessed amount of unpaid tax (Case Nr. A42314305 SKA - 502/2008, para. [15]).

As we see the taxpayer interests/rights doesn't play any important role in the implementation of the institute of the settlement agreement. Such a denying of the taxpayer's role doesn't correspond to the legal nature of the settlement agreement. As it stated in the above mentioned case the settlement agreement has almost different legal nature in comparison with the administrative act which is the

This is an Open Access article distributed under the terms of the Creative Commons Attribution License 2.0, which permits unrestricted use, distribution, and reproduction in any medium, provided the original work is properly cited. 


\section{SHS Web of Conferences}

unilateral instrument of the public authority (Ibid, para. [13]). The settlement agreement in the tax law is the administrative agreement in the context of the State Administrative Structure Law. The section 79. of this law states that "Administrative contracts are agreements between public persons and private individuals regarding the specification, amendment, termination or determination of administrative legal relations..." This definition produces the almost different approach - acceptance of the active role of the taxpayer in conclusion of such an agreement, but it strongly conflicts with existing legal regulation.

According to the Law on Taxes and Fees section 41. "Entering into of a Settlement Agreement by the Tax Administration and Taxpayer" taxpayer is entitled to propose to the director-general of the State Revenue Service to enter into of settlement agreement with State Revenue Service. The conclusion of such an agreement has two legal conditions:

1) the taxpayer acceptance of the amount of additional tax payment assessed by the State Revenue Service,

2) the taxpayer obligation to pay the amount of additional tax payment. The legal consequences of the settlement agreement are that 1) the assessed fine is revoked in the whole sum 2) the assessed delay penalty is revoked partly (50\%). The model shall be called "Penalty model".

But, the director-general of the State Revenue Service has no free right to enter into a settlement agreement, such a general condition as the fact that the taxpayer on the day, when the submission regarding the entering into of a possible settlement agreement is submitted, has no current tax debt should be observed. One of the under mentioned conditions should exist as the additional factors which entitle the taxpayer to conclude the settlement agreement:

1) the decision of the director of the State Revenue Service territorial office is disputed, and, in examining the submission of the taxpayer, the director-general of the State Revenue Service territorial office has left the disputed decision unchanged or also has taken a new decision with which the disputed decision is partially revoked; or

2) the taxpayer has submitted a complaint to a court, but the adjudication of the matter has not been commenced on the merits.

In deciding the issue regarding the entering into of a settlement agreement, the reasons for the creation of the tax debt and the amount shall be taken into account, as well as the efficiency of continuing the dispute and the costs associated thereto.

The conclusion of the settlement agreement has a strong restriction that is a settlement agreement shall not be entered if the tax administration has submitted materials for a decision on the issue of bringing a criminal action.

Till 03.04.2001 the construction of this norm was almost different and it stated that the directorgeneral of the State Revenue Service is entitled to enter into of settlement agreement with the taxpayer. The legal consequence of such an agreement is the reduction of the amount of additional tax payment assessed by the State Revenue Service. This norm could be used only in the cases when the implemented norms which are the legal basis of the dispute between taxpayer and State Revenue Service are contradictory and disputable. This model shall be called "Basic debt model".

So, the crucial question in the discussion of implementation of the settlement agreement in tax matters is the question which of the above mentioned models is better (more efficient in economic sense and more legal - consider the rights of taxpayer and state in the most optimal way): the revocation of the assessed fine and delay penalty or the reduction of the amount of additional tax payment assessed by the State Revenue Service (which include as the basic sum of unpaid tax payment, as assessed fine and delay penalty).

According to the existing legal model of the settlement agreement the taxpayer interests/rights don't play any important role in the implementation of the institute of the settlement agreement. Such a 
Int. Conf. SOCIETY. HEALTH. WELFARE; Congr. of Rehabilitation Doctors of Latvia

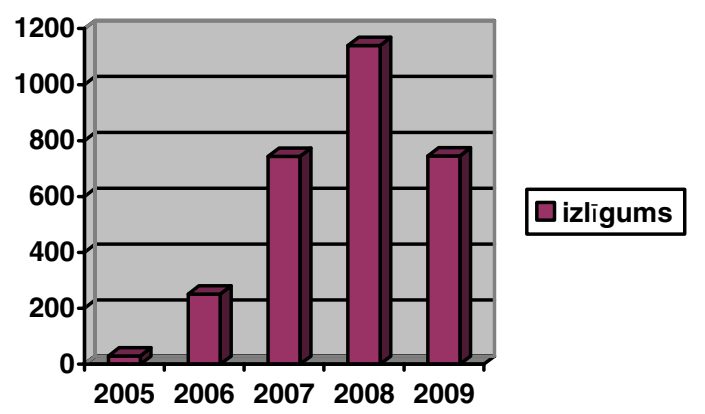

Figure 1. The dynamics of the inquiries on the entering into settlement agreement in criminal offences (in absolute numbers).

denying of the taxpayer's role doesn't correspond to the legal nature of the settlement agreement. As it stated in the above mentioned case the settlement agreement has almost different legal nature in comparison with the administrative act which is the unilateral instrument of the public authority (Case Nr. A42314305 SKA - 502/2008, para. [13]).

The settlement agreement in the tax law is the administrative agreement in the context of the State Administrative Structure Law. The section 79. of this law states that "Administrative contracts are agreements between public persons and private individuals regarding the specification, amendment, termination or determination of administrative legal relations..." This definition produces the almost different approach - acceptance of the active role of the taxpayer in conclusion of such an agreement, but it strongly conflicts which existing legal regulation.

As the professor Braithwaite says: "The hard question is how we decide when to punish and when to persuade?" (Braithwaite, 2002; 19). In order to answer this question the responsive regulation strategy suggests to use the so - called "regulatory pyramid" that is the algorithm of decision making. "At the base of the pyramid is the most responsive dialogue - based approach we can craft for securing compliance just with law. As we move up the pyramid, more and more demanding and punitive interventions in people's lives are involved. The idea of the pyramid is that our presumption should always be to start at the base of the pyramid, than escalate to somewhat punitive approaches only when modest forms of punishment fail" (Ibid; 20).

The role of the settlement agreement in the existing configuration - "Penalty model" as the tool of the responsive dialogue unfortunately is not analyzed not from the sight of the State Revenue Service nor the Ministry of Finance; there is no statistic data depicting the dynamics and factors motivating of the entering the settlement agreement or not doing so. The only fact that is obvious is the fact that tax debts calculated by the State Revenue Service stayed unpaid in 2010 (statistic data for the 9.months period) is the amount of 99, 3 millions of lats (www.vid.gov. $1 \mathrm{v}$ ).

So, in order to analyze the effectiveness of the settlement agreement in a starting stage of the responsive dialogue, the role of the settlement agreement in the other area than the area of taxes could be analyzed. For the adequate sphere of comparison the criminal law area could be chosen. The legal model of the tax disputes has much in common with the disputes in criminal offences. This thesis is based on the resent case law of the European Court of Human Rights (cases: Västberga Taxi Aktiebolag and Vulic v. Sweden, Funke v.France, Salabiaku v. France, "Bulves"AD v. Bulgaria), that bases the legal analyses of the above mentioned tax disputes on the interpretation of criminal law principils.

According to the Criminal Procedure Law section 381. the settlement procedure ensures the State Probation Service. The settlement "is possible in criminal proceedings, and that the involvement of an intermediary is useful, a person directing the proceedings may inform the State Probation Service regarding such possibility or usefulness." The organization of the entering procedure of the settlement agreement State Probation Service has started in the 2005, and, as it seen in the Figure Nr.1 the use of 


\section{SHS Web of Conferences}

these legal remedy has an obvious prompt dynamics. According to the data of the State Probation Service the biggest amount of the settlement agreement inquiries is in the criminal charges for commitment the theft. (Central Office of the State Probation Service. The public overview for the year of 2009, p.15).

The data of the Central Office of the State Probation Service. The public overview for the year of 2009, p.15 (www.probacija.lv).

Such a dynamics get the basement to make a conclusion that the use of settlement agreement could be an effective remedy in the settlement of legal disputes. But, the question that remains is the question why such a remedy taking into account the amounts of assessed taxes that is not paid back to the state is not effectively used in the tax disputes. The answer could be simple: the existing "Penalty model" isn't attractive for the taxpayers. So the next research question is why: what are the reasons legal, economic or psychological, or all in one?

An essential instrument of responsive regulation in taxation is the "tailoring punishment so that a concession is made for self-regulatory effort". The tailoring punishment model has been chosen for the reasons of "process efficiency and outcome consistency" (Braithwaite, 2007). The tailoring punishment basis is the formation element of the Australian Taxation Office Compliance Model, which has been invented in the year of 1998 and since then been exported and adapted by the other jurisdictions (UK, New Zealand, Indonesia and within the US) (Ibid).

The tailoring punishment concept fully corresponds to the public choice theory which emphasizes the material interests citizens have in enacting or defeating legislation, an attention to norms reveals that people are highly motivated to create rules that may not affect their material interests (McAdams, Rasmusen, 2004). In the case of Latvia one of the possible reasons of not active use of the settlement agreement as a remedy of solving the tax dispute is the lack of material interests from the sight of the taxpayer: the legal consequences of the settlement agreement in the "Penalty model" which are: 1) the assessed fine is revoked in the whole sum 2) the assessed delay penalty is revoked partly are considered not material attractive, and so the whole model is rejected.

One more factor that could explain the low effectiveness of the settlement agreement of the "Penalty model" is the lack of the "positive action" from the sight of the tax authority in the taxpayer interpretation. According to the resent research of the psychological aspects in the relationship between taxpayer and tax authority the interesting finding has been considered: "The relationship between taxpayers and state can be seen as a relationship or psychological contact, which involves strong emotional tiers and loyalties. Such a psychological tax contract can be maintained by the positive action" (Torgler, 2008). Settlement agreement of the "Penalty model" possibly doesn't associated to the taxpayer's with the positive action of the tax authority, it could be particularly truth to the situations when the basement of the dispute between taxpayer and tax authority is thecontroversial legal norms. It should be mentioned that the situation of controversial legal norms is common in tax law. Such a situation is constrained with the very character of tax law and the its forming legal norms. Hart HLA has stated that rules have a core meaning and a penumbra where their meaning is more uncertain. The more complex phenomenon is regulated, the wider the penumbra is likely to be (Braithwaite, 2005). The object of the regulation of the tax law is the complex area that tends to regulate many domains in one time: economic, legal, political. So, it is obvious that the tax legislation contains an enormous amount of the controversial legal norms. In some jurisdictions, for example - Russian federation, tax legislation consists the legal rule according to which all irremovable contradictions of tax legislation should be interpreted in the favor to the taxpayer (Tax Code of the Russian Federation Section 3. paragraph 7). Such a regulation could be considered as the element of responsive regulation in taxation and as an effective basement for the positive action of ht tax authority. Unfortunately, Latvian tax legislation doesn't contain such a legal regulation; however, such a legal norm could be a starting legal point for the implementation of the settlement agreement of the Basic debt model. However, such a legal norm in the absence of the effective model of the settlement agreement in practice could be implemented and interpreted in the court decisions in a very provocative way denying the very legal character of it - the case of Russia proves this thesis (see the detailed review of the court's interpretation of this norm in 
Int. Conf. SOCIETY. HEALTH. WELFARE; Congr. of Rehabilitation Doctors of Latvia

the research of Нагорная Э.Н. Налоговые споры оценка доказательств в суде. Москва: Юстицинформ 2009, с. 41-44).

After such a severe critics of the Penalty model the benefits of the Basic debt model should be analyzed. In the resent research in tax compliance on the first front the have come the non-economic factors of the compliance. It has been stated in the empirical way that such a notions as justice and fairness play an important role in taxpayer's evaluations of the tax system and in their decision to comply or not comply with tax laws (Wenzel, 2003). Wenzel sees the tree areas of justice: distributive justice, procedural justice and retributive justice. In the author's view settlement agreement belongs to the remedies of the retributive justice. According to the Wenzel definition retributive justice reefers to the fairness of sanctions and reactions to the breaking of social rules and norms. "Deservingness of the punishment should depend on the perceived importance of the violated rule, the severity of rule violation and degree of responsibility an blame attributed to the actor" (Ibid). The fact is obvious in the cases when controversial legal norm is a matter of tax dispute. In such situation the level of perceived importance of the rule violated is close to zero: the taxpayers feels itself as a person who doesn't deserve the punishment, but have no chance to prove it in a legal way or come to the adequate decision which could respect the interests of the both parts of the dispute and ensure the right on different interpretation of the disputable legal norm. In such cases the Basic debt model is the "fair price" for inability of the state to formulate precise the limits of legal permissions and prohibitions.

\section{Conclusion}

1. The use of the settlement agreement in existing legal framework of Latvian tax law has many controversial aspects: the regulation is not responsive. 2. The existing legal model of the settlement agreement belongs to the models of deterrence punishment and doesn't consider interests of taxpayers. 3. The effective model of the settlement agreement should take into account as well as the economic as the social aspects that motivates taxpayer to enter the settlement agreement. 4. The legal criteria of controversial legal regulation for conclusion the settlement agreement is the proper legal basis. 5. The Basic debt model has more positive aspects then Penalty model 6. The section 41. of the Law on Taxes and Fees should be changed to the legal model of the Basic debt model.

\section{References}

[1] Anonymous. (2009) The public overview for the year of 2009. State Probation Service of the Republic of Latvia.

[2] Braithwaite, J. (2005) Markets in Vice Markets in Virtue. Oxford: Oxford University Press, p. 146.

[3] Braithwaite, J. (2002) Rewards and Regulation. Journal of Law and Society. Volume 29, No.1, p. 12-26.

[4] Braithwaite, V. (2007) Responsive regulation and Taxation: Introduction. LAW\&TAX, Vol.29, No.1.

[5] McAdams R.H., Rasmusen E.B. (2004) Norms in Law and Economics. Handbook of Law and Economics, p. 1-49.

[6] Torgler, B., Schneider, F., Schaltegger, C.A. (2008) Local Autonomy, Tax Morale and the Shadow Economy. Center for Research in Economics, Management and the Arts. Working Paper No. 2008, 24, p. 2-39.

[7] Wenzel, M. (2003) Tax Compliance and the Psychology of Justice: Mapping the Field. Taxing Democracy: Understanding Tax Avoidance and Evasion. Aldershot, UK: Ashgate Publishing Limited, p. 42-69. 


\section{SHS Web of Conferences}

[8] Нагорная Э.Х. (2009) Халоговые споры оценка доказательств в суде. Москва: Юстициформ, с. 41-44.

[9] The Law of the Republic of Latvia on Taxes and Fees.

[10] Latvian State Administrative Structure Law.

[11] The Criminal Procedure Law of Latvian Republic.

[12] Tax Code of the Russian Federation.

[13] The Supreme Court of the Republic of Latvia The Department of the Administrative Law. 25 september of the 2008. The decision of the Court in Case Nr. A42314305 SKA - 502/2008.

[14] European Court of Human Rights, Case of Västberga Taxi Aktiebolag and Vulic v. Sweden, Application No. 36985/97. Final judgment. 23 July, 2002.

[15] European Court of Human Rights, Case of Funke v. France, Application No. 10828/84. Final judgment. 25 February, 1993.

[16] European Court of Human Rights, Case of Salabiaku v. France, Application No. 10519/83. Judgment. 7 October, 1988.

[17] European Court of Human Rights, Case of “Bulves”AD v. Bulgaria, Application No. 3991/03. Final judgment. 22 April, 2009. 